\title{
THE ART OF SKILFUL NEGOTIATING
}

\section{KAREN TRACE*}

This article is a comprehensive outline of the rationale behind and the skills involved in alternative dispute resolution. A discussion on the nature of conflict leads to the submission that convergent negotiation is a more efficient means of settling disputes, as opposed to the divergent negotiations that are typified by conventional adversarial negotiation. This is followed by $a$ discussion of the various theories on negotiations.

The processes and rationale involved in interestbased negotiations are then reviewed. A condition precedent to the process is to get the parties to realize that they have a common problem that must be solved collectively, and not that one party must "win" at the expense of the other. The key skills and attributes of a successful interest-based negotiator are outlined: the negotiator must focus on the problem, use appropriate communication techniques, set the tone for mutual gain, prepare properly for negotiations and practice frequent selfevaluation. The article concludes with a complete framework designed to lead to successful negotiations.
Le présent article décrit la raison d'être du règlement de différends sans recours aux tribunaux, ainsi que les habiletés qu'il requiert. Partant d'une discussion sur la nature des conflits, l'auteure suggère que la négociation convergente est un moyen plus efficace de résoudre les conflits que la négociation divergente illustrée par la négociation accusatoire traditionnelle. Suit une discussion des diverses théories de la négociation.

Les processus et le bien-fondé de la négociation à la satisfaction des parties sont ensuite passés en revue. Il convient avant tout d'amener les intéressés à comprendre qu'ils ont un problème commun $\dot{a}$ résoudre collectivement, et non pas que l'un d'eux doit gagner aux dépens de l'autre. Les habiletés et caractéristiques majeures d'une négociation de ce type sont décrites : le négociateur doit se concentrer sur le problème, utiliser des techniques de communication appropriées, établir un climat axé sur les gains mutuels, se préparer correctement aux négociations et pratiguer souvent son autoévaluation. L'article conclut en offrant un cadre complet destiné $\dot{a}$ assurer le succès des négociations.

\section{TABLE OF CONTENTS}

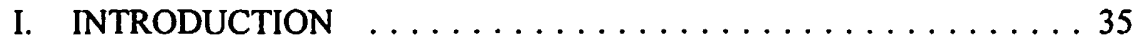

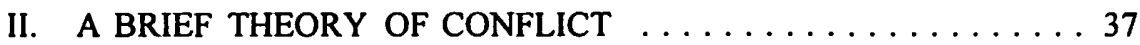

III. DEFINING THE SUCCESSFUL NEGOTIATION $\ldots \ldots \ldots \ldots 38$

A. DIVERGENT OR CONVERGENT NEGOTIATIONS? . . . 38

IV. VARIOUS THEORIES ON NEGOTIATIONS .......... 39

A. DISTRIBUTIVE $v$. INTEGRATIVE NEGOTIATIONS ... 39

B. COMPETITIVE v. COOPERATIVE NEGOTIATIONS .... 40

C. GOAL-BASED $v$. PROCESS-BASED NEGOTIATIONS $\ldots 40$

V. AN INTRODUCTION TO INTEREST-BASED

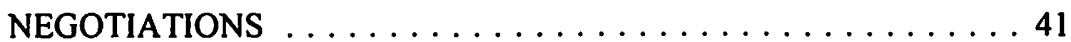

VI. THE INTEREST-BASED NEGOTIATOR $\ldots \ldots \ldots \ldots \ldots \ldots 46$

VII. RECOMMENDED SKILLS AND TECHNIQUES $\ldots \ldots \ldots \ldots 47$

A. FOCUS ON THE PROBLEM $\ldots \ldots \ldots \ldots \ldots \ldots \ldots 47$

B. USE APPROPRIATE COMMUNICATION TECHNIQUES .. 48

McCuaig Desrochers, Edmonton. This article closely follows day one of the Legal Education Society of Alberta Bar Admissions materials 1994-95 which were co-designed and co-written by Karen Trace, Camilla Witt and Tannis Carlson. Accordingly, the writer would like to acknowledge the contributions of Camilla Witt and Tannis Carlson who are lawyers with Alberta Justice in Edmonton. 
C. SET THE TONE FOR MUTUAL GAIN ........... 49

D. PREPARING FOR NEGOTIATIONS ............ 50

E. PRACTICE FREQUENT SELF-EVALUATION $\ldots \ldots \ldots \ldots 1$

VIII. A COMPLETE FRAMEWORK FOR

SUCCESSFUL NEGOTIATIONS $\ldots \ldots \ldots \ldots \ldots \ldots \ldots \ldots 2$

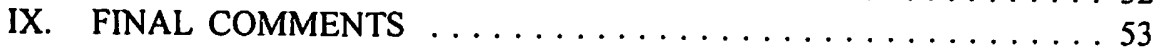

\section{INTRODUCTION}

There are few today who would disagree with the view that negotiating is not only an art but a skill. This view is supported by law societies throughout Canada and North America who have seen fit to include the topic in their bar admissions curricula, and for good reason, they say. As a result of several surveys conducted on the topic of negotiations, legal educators have expressed concern over the apparent variation in skill levels among practicing members of the bar. Oft-cited is the study by Gerald Williams, Associate Dean and Professor of Law at Brigham Young University in Utah.' The study arguably asks more questions than provides answers, but its results are certainly provocative.

The set-up is fairly straight-forward:

- forty experienced lawyers participated;

- they were asked to prepare and conduct negotiations concerning a personal injury matter;

- half were assigned to represent the plaintiff; the other half the insurer;

- the lawyers were provided with identical facts in one jurisdiction;

- relevant caselaw was provided;

- $\quad$ they had two weeks to prepare;

- results and names would be published (nothing like the threat of humiliation).

Here are the results:

\begin{tabular}{|c|c|c|c|}
\hline Attorney & $\begin{array}{c}\text { Plaintiff's Opening } \\
\text { Demand }\end{array}$ & $\begin{array}{c}\text { Defendant's Opening } \\
\text { Demand }\end{array}$ & Settlement \\
\hline 1. & $\$ 32,000$ & $\$ 10,000$ & $\$ 18,000$ \\
\hline 2. & $\$ 50,000$ & $\$ 25,000$ & no settlement \\
\hline 3. & $\$ 675,000$ & $\$ 32,150$ & $\$ 95,000$ \\
\hline 4. & $\$ 110,000$ & $\$ 3,000$ & $\$ 25,120$ \\
\hline 5. & Not reported & Denied liability & $\$ 15,000$ \\
\hline
\end{tabular}

I G.R. Williams, Negotiations and Settlement in the 1990s, New Dimensions for Lawyers (Minnetonka: Professional Education Group Inc., 1992). 


\begin{tabular}{|c|c|c|c|}
\hline Attorney & $\begin{array}{c}\text { Plaintiff's Opening } \\
\text { Demand }\end{array}$ & $\begin{array}{c}\text { Defendant's Opening } \\
\text { Demand }\end{array}$ & Settlement \\
\hline 6. & $\$ 100,000$ & $\$ 5,000$ & $\$ 25,000$ \\
\hline 7. & $\$ 475,000$ & $\$ 15,000$ & no settlement \\
\hline 8. & $\$ 180,000$ & $\$ 40,000$ & $\$ 80,000$ \\
\hline 9. & $\$ 210,000$ & $\$ 17,000$ & $\$ 57,000$ \\
\hline 10. & $\$ 350,000$ & $\$ 48,500$ & $\$ 61,000$ \\
\hline 11. & $\$ 87,500$ & $\$ 15,000$ & $\$ 30,000$ \\
\hline 12. & $\$ 175,000$ & $\$ 50,000$ & no settlement \\
narrowed to & & $\$ 137,000-$ \\
& & & $\$ 77,000$ \\
\hline 13. & $\$ 97,000$ & $\$ 10,000$ & $\$ 57,500$ \\
\hline 14. & $\$ 100,000$ & -- & $\$ 56,875$ \\
\hline & & Average Settlement: & $\$ 47,318$ \\
\hline
\end{tabular}

Note the highest and lowest opening demands. I'll think you'll agree, the range is a bit disturbing. Not only is the initial assessment by each lawyer a concern, but so too are the results. Depending on the lawyer retained, the client might have obtained either no settlement at all or obtained a settlement ranging anywhere from $\$ 18,000$ to $\$ 95,000$. We are urged by Williams to draw the following conclusions:

1. Legal experience is not necessarily a good teacher of negotiating skills.

2. Clients are the ones that suffer from the variation in skills.

While it may be argued that this experiment does not eliminate all the extraneous variables, in the final analysis the degree in variation of skill level is difficult to explain away. It is in this context that growing interest in the study of negotiation has arisen. Studies such as the Williams study have resulted in a plethora of writers and educators committed to establishing negotiation as a recognized skill and setting up theoretical models for skill development. This article will attempt to provide you with a sample of some of the educational writers in this field. Several theories will be examined with emphasis on one highly respected model for negotiating. This article will conclude with an examination of those characteristics associated with a successful negotiator and will offer a step-by-step framework which is designed to lead to successful negotiations. 


\section{A BRIEF THEORY OF CONFLICT}

In order to evaluate negotiation as a skill, educators suggest first examining the underlying reasons for negotiating. Why do we negotiate? Conflict, of course. It's the stuff that lawyers are made of. Without conflict, we would be out of business. As lawyers and legal writers, we typically negotiate as a result of conflicts over interpretation of the law or perhaps competing claims. In other contexts, conflict results from difficulties over goals, beliefs and philosophies; roles, responsibilities and boundaries; approaches to problem solving, limited commodities and the value of those commodities.

Of course, the word "conflict" generally carries a negative connotation. However, two theorists have suggested that the process of conflict can and should be viewed as being comprised of both a negative (divergent) and a positive (convergent) force. Folberg and Taylor best summarize their theory as follows: ${ }^{2}$

- As a negative or divergent force, conflict can feel like a crisis. A crisis mentality can result in disaster. The destructive aspects of conflict push people to take extreme measures to end the conflict and avoid disaster. Ending the conflict is not necessarily resolving the conflict. When the conflict reaches crisis proportions, it is often an inopportune time to resolve the underlying basis for the conflict.

- As a positive or convergent experience, conflict results in such benefits as:

- relief from stagnation;

- stimulation;

- prevention of more serious strife;

- increased group cohesion and performance.

Conflict can be a positive catalyst for change and development.

For our purposes, this theory of conflict can be expanded to include negotiation as a method of conflict resolution. Arguably, negotiation can also be either divergent or convergent in nature. As a negative or divergent experience, negotiation can be a way to end conflict temporarily without resolving the root of the conflict. As a positive experience it can create change and actually improve relationships between the parties. Several educators have seized upon this latter approach as the foundation for developing the model of a successful negotiation. 


\section{DEFINING THE SUCCESSFUL NEGOTIATION}

Scene One: The deal is done. It has been an acrimonious battle and you hope you never have to deal with that lawyer again. Despite the bad feelings between you and your adversary, you feel the negotiation has been successful. The relief you've obtained for your client is in accordance with the latest Court of Appeal judgment.

Scene Two: You contact the client and obtain her instructions for approval of the deal. She isn't overjoyed. The client complains, "I still don't feel like the real issues have been dealt with." You explain to her that had she gone to court she probably wouldn't have been entitled to any more. Despite these reservations, the lawyers exchange documents and the consent order is obtained.

Scene Three: Three months later you receive a call from the other lawyer. He says your client isn't living up to her end of the bargain. You contact her. She refuses to be bound by the agreement. The same "real issues" are bothering her. She's accusing you of not listening to her instructions. The deal is a bust.

\section{A. DIVERGENT OR CONVERGENT NEGOTIATIONS?}

There is a strong argument to be made that this scenario tends to describe divergent negotiations. While the "result" may have been obtained in accordance with accepted professional standards, the negotiation could be described as unsuccessful for a number of other reasons. From the client's perspective, the negotiation didn't resolve the conflict; there were deep-seated issues left unresolved by the negotiation. The ultimate result of these problems was failure at the implementation stage. In addition, although the result may have felt like a "victory," the process was less than satisfactory. The cost was high in terms of damaging future relations between the negotiators. (We all know the importance of reputation and relationships in the legal community).

Damaging future relations and implementation failure are just a few of the divergent or unsuccessful aspects of negotiating that have been documented by various scholars. This list has been expanded to include such phrases as "atmosphere of competition" and "one side feels taken." On the other side it could be said that a successful or "convergent" negotiation "leaves both sides feeling satisfied" and "leaves relationships intact." Of course you may disagree with these criteria for a successful negotiation. What is your view of a successful or unsuccessful negotiation? Below is a list used by the Canadian Dispute Resolution Corporation in one of their manuals. ${ }^{3}$

Canadian Dispute Resolution Training Manual (Calgary: Canadian Dispute Resolution Corp., 1995) at 15. All rights reserved to Canadian Dispute Resolution Corporation, No. 200, 17413 - 107 Avenue, Edmonton, Alberta, T5S IE5. For further information concerning the use of this manual, or course-manuals on dispute resolution generally, call Dennis Leonard at 1-403-484-6627 or fax 1-403-484-3484. 


\begin{tabular}{|c|c|}
\hline SUC & UNSUCCESSFUL \\
\hline $\begin{array}{l}\text { - Both sides satisfied } \\
\text { - Leaves relationships intact } \\
\text { - Feels real issues have been dealt with } \\
\text { - Use of creative solutions } \\
\text { - Results based on objective criteria } \\
\text { - Atmosphere of collaboration and openness } \\
\text { - Decision based on: exploration, fairness, } \\
\text { objective criteria, mutual interests } \\
\text { - Mutual interests } \\
\text { - Likelihood of an improved working } \\
\text { relationship } \\
\text { - Likely to be upheld } \\
\text { - Us v. The Problem }\end{array}$ & $\begin{array}{l}\text { - One side feels on short end of stick } \\
\text { - One side feels hurt } \\
\text { - Feels only the superficial issues have been } \\
\text { resolved or that an important issue or fact } \\
\text { was not considered } \\
\text { - Atmosphere of horse trading } \\
\text { - Settlement pulled out of the sky } \\
\text { - Atmosphere of competition, mistrust } \\
\text { - Decision based on: compromise, pressure, } \\
\text { - Mutual needs } \\
\text { - Likelihood of a less effective future working } \\
\text { relationship or no relationship at all } \\
\text { - Refuses to live up to deal } \\
\text { - Prone to be sabotaged } \\
\text { Me v. You, Us. } v \text {. Them }\end{array}$ \\
\hline
\end{tabular}

\section{VARIOUS THEORIES ON NEGOTIATIONS}

The characteristics of a successful negotiation suggested above have been reshaped by various writers into a number of theories on negotiations. The most well known perhaps is the theory of "principled negotiations" or "interest-based negotiations" formulated by Robert Fisher and William Ury. Many of you will know the book Getting to Yes and other publications by this duo from the Harvard Negotiation Project. ${ }^{4}$ Before proceeding to examine the Fisher/Ury framework, it is useful to take a look at a number of other theories on negotiating. Gordon Sloan, a lawyer from Salt Spring Island, British Columbia, and an educator in the field of negotiation and mediation, has compiled several theories which serve as an introduction to the interestbased model. $^{s}$

\section{A. DISTRIBUTIVE v. INTEGRATIVE NEGOTIATIONS}

This theory contrasts the difference between "dividing up the pie" and "expanding the pie." The distributive approach is defined as one in which the parties view the resources available as pre-determined. The negotiation process is a competition to obtain the largest portion of those resources at the expense of the other. In contrast, the integrative approach has the parties "integrating their resources" to find the best solution

\footnotetext{
R. Fisher \& W. Ury, Getting To Yes: Negotiating Agreement Without Giving In (Harmondsworth, England: Penguin Books Ltd., 1992).

$5 \quad$ G. Sloan, Conscientious Building Through Principled Negotiation: A Workshop in Multi-Party Negotiations (Edmonton: Dept. of Environmental Protection, 29-31 March 1994) at 3.01.
} 
to the problem. ${ }^{6}$ For example, during negotiations over a wrongful dismissal, the parties might expand the pie beyond payment of damages for the disputed period of reasonable notice. Pie expansion might include providing for a letter of reference, creating a new job opportunity, arranging for future contract work or placement in a training program. All of the options would be unavailable if litigation proceeded to court. In a dispute over an estate matter, integrative solutions might include sharing space in the disputed homestead or exchanging title for another property.

\section{B. COMPETITIVE v. COOPERATIVE NEGOTIATIONS}

This theoretical framework is likely the most familiar of the three and results in the most heated debate. This model is based on the styles or patterns of the negotiators.

Competitive: Each party pursues satisfaction of own objectives, possible solutions are pre-determined, preferred approach is adversarial.

Cooperative: The objective is a solution which is agreeable to both parties, tendency is to compromise and make unilateral concessions, solution should be based on moral sense of fairness.

Writers such as Williams suggest that both patterns or styles have their strengths and weaknesses. ${ }^{7}$ Depending on the pathology, both patterns can be effective or ineffective. Still other academics suggest that style without a philosophy or methodology cannot form the basis for successful negotiations, particularly if success is measured over time. The subject of style will be examined later under the topic of the "Successful Negotiator."

\section{GOAL-BASED v. PROCESS-BASED NEGOTIATIONS}

According to Sloan, this theoretical juxtaposition takes a slightly different approach. While the first two methodologies outlined above address the "how to" or "process" of negotiating, the goal-based approach focuses on the objects of the negotiation. In a sense this view attempts to "side-step" the debate over style. The goals or objects of the negotiation might include meeting the client's short term and long term needs, advancing the relationship which the client seeks with the other party, fairness, and keeping down costs.

These are several of the theories which have been developed to deal with the various forces at play in the negotiating process. The remainder of this article will focus on the theory of interest-based negotiations, first developed by Fisher/Ury and expanded by several others. This approach appears to borrow from each of the above theories and then wraps them up in a practical approach which is designed to result in greater success over time. 


\section{AN INTRODUCTION TO INTEREST-BASED NEGOTIATIONS}

The framework for interest-based negotiations can best be described by what it is not. Fisher and Ury contrast interest-based negotiations with positional negotiations. The following scenario is an illustration of the latter.

\section{The Shopping Mall Dispute}

Lawyer Bob: Joan, how can you threaten our client with legal action when it is your client who has clearly breached the lease? Your client is selling wickerware goods when clause 4 of the lease states in black and white your client can only sell leather goods. Our client has every right to lease new space in the mall to a tenant who wants to sells wickerware. Your client is the one who has to worry about a law suit.

Lawyer Joan: Come now Bob, maybe your client should read the lease. Clause four states:

"The lessor covenants with the lessee not to rent space in the mall for use as a leather goods store, dry goods, leather products outlet or any type of operation similar to that of the lessee."

You and I both know that the phrase "similar goods" is specifically designed to deal with expansion into the sale of such goods as wickerware. The court decision in Northwest Mall interprets exactly the same kind of clause. If your client lets that space to Wickerware Inc. we'll have no choice but to sue.

Lawyer Bob: But Joan, the Northwest Mall case looked at the similarity between "fast food" and "hamburgers." The difference between leather goods and wickerware is like night and day. My client has more than enough money to challenge you on that kind of analogy.

This kind of negotiation is one in which the negotiators start by assuming a "position." The position is based on preparation and assessment completed before arriving at the negotiating table. Each lawyer has examined the issues: interpretation of the lease, the right to sell certain goods and the right to let mall space to another tenant. They have looked at their own client's resources, evaluated their chances of success at litigation and have developed a position which resolves the problem in their client's favour. Little attention is paid to the other side's perspective. 
In this case, the landlord's position is to force the old tenant to stop selling wickerware. The position held by the tenant is to prevent the operation by the new tenant. The trenches are already deep. Maybe one of the negotiators will move a couple of feet and re-dig. Maybe neither will move. If they don't move, they're bound for court.

We have all experienced this feeling. In this kind of process, progress is difficult. The reason, according to Fisher and Ury, is that compromise will come at a high cost. The party compromising his or her position must necessarily experience a loss of face. One party's gain is at the expense of the other party. Even if agreement is reached, no one feels happy because they have had to concede their position. In addition, the result is arbitrary and based on force and concession-making.

\section{Positional negotiating is a painful process because one party's gain is the other party's loss.}

Interest-based negotiating takes an entirely different approach. Interest-based negotiating is when the parties examine each others' interests, avoid taking positions, and generate solutions which embody the parties' interests. Rather than coming to the table having already formulated a solution to their own problem, they start by exploring interests. The key to interest-based negotiating is to avoid digging trenches. Consider the following illustration:

Two students in a library were in the midst of a dispute over whether a window should stay open or closed. One student would get up to open the window to bring in a breeze, the other would shut the window to avoid his papers from being blown around. The librarian noticed the commotion and approached the students asking both what was the matter. The one complained that she was too hot; the other complained about the effect on his papers. The librarian inquired into the interests of the two students, namely air circulation for one and preventing disruption for the other. In seeking a solution that appealed to both interests, the three resolved to open a window in another room, thus creating air flow without the direct breeze."

An interest-based approach shifted the focus from the positions of the parties. Solutions were generated which met the interests of both parties. By focusing on interests, the pie was expanded to include other options.

Fisher and Ury describe the steps as follows: 
1. Start by examining the interests of the parties.

Interests are the client's needs, desires, concerns, fears and hopes.

Interests are the underlying reasons for taking a position.

2. Identify mutual and complementary interests.

3. Focus on generating options which meet as many of these mutual and complementary interests as possible.

Brainstorm for solutions without commitment.

Leave evaluation of the solutions until brainstorming is complete.

In the case of the shopping mall dispute this process could be applied as follows:

1. Landlord's interests: - maintaining a full mall, avoiding black spaces

- keeping long term tenants in the mall

- minimizing the expenses associated with high turnover

- maintaining the appropriate mix of tenants and synergy of shops

- maintaining friendly tenant relations

- minimizing legal expenses

- maintaining reputation

Tenants interests: - remaining economically viable, protecting investment

- fear of competition from new tenant

- maintaining a long term presence in the mall

- keeping down rent costs

- maintaining certainty of costs over the long run

- keeping down legal expenses

- maintaining good relations with landlord and other tenants 
2. Mutual/Complementary Interests

Landlord

- maintaining a full mall

- long term tenants/leases

- keeping down legal expenses

- maintaining tenant relations

- friendly relations
Tenant

- remaining economically viable

- long term presence in the mall

- certainty of costs over the long run

- keeping down legal expenses

- maintaining landlord relations

- friendly relations

3. Inventing Options for Mutual Gain

- looking at the possibility of allocating space to the new tenant in such a manner as to ensure appropriate distance between the shops

- looking at the possibility of moving the old tenant to a better space

- reopening the lease and looking at rental rates, length of lease, and type of goods sold to ensure viability and to eliminate fear of any competition

In this shopping mall example, by examining the interests of the parties first, it is suggested that the focus can be shifted away from taking positions. In addition, the focus on interests shifts parties away from interpretation of clause four of the lease. Arguably that issue is one which can't be resolved by the parties and should be put aside for the purposes of the negotiation. In inventing options for mutual gain the parties are putting more on the table than was available to them at initial glance. The "pie" is expanded to include the re-opening of the lease and renegotiation of terms for mutual gain. These options would not have been available to the parties had they continued to "horse trade" their positions. It is important to also note that these options would not be available to a court should the matter proceed to trial.

Another way to illustrate the comparison between positional-based negotiating and interest-based negotiating is with the following diagram. ${ }^{10}$ 


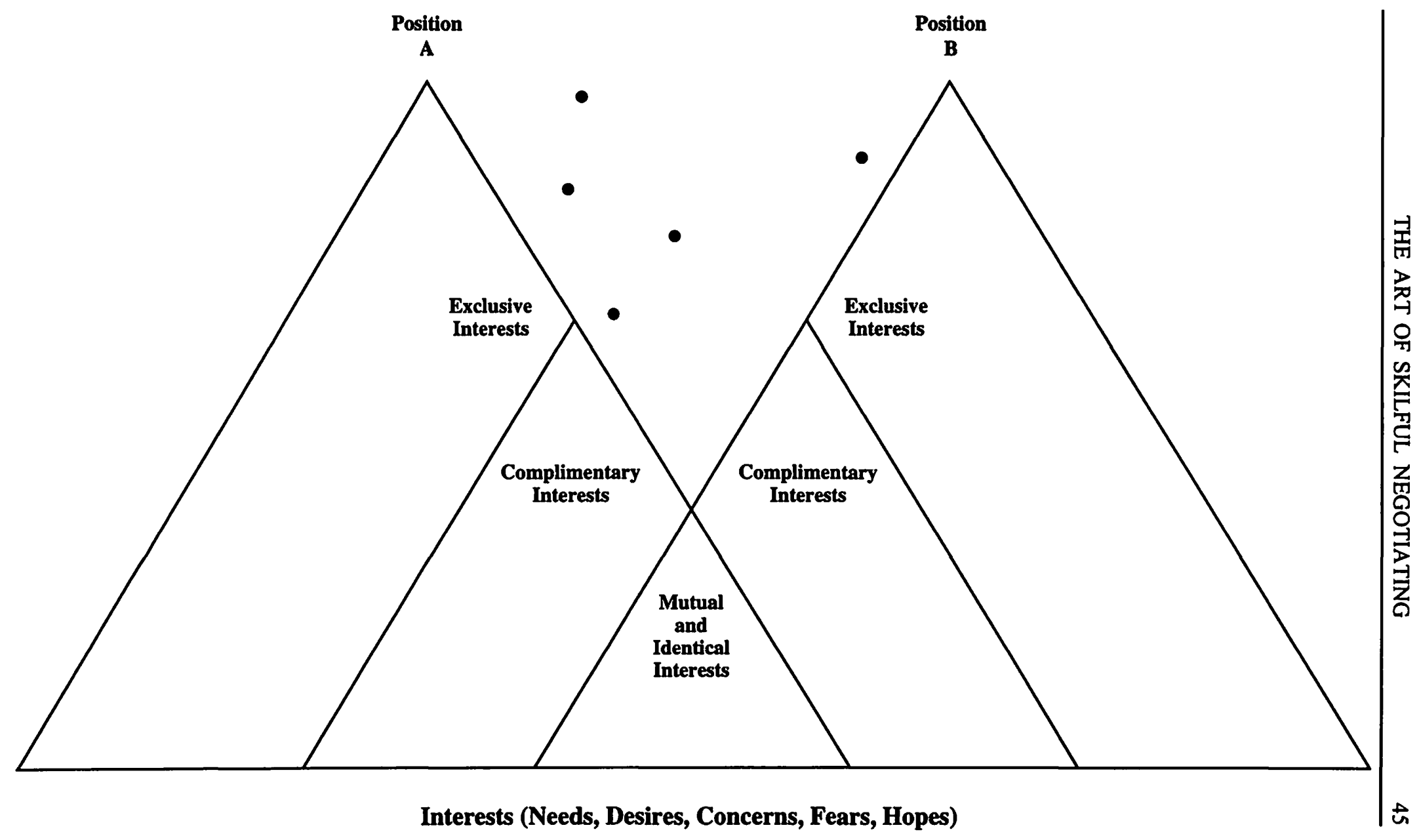


In position-based negotiating, compromise results in a solution which does not necessarily meet the interests of either party. A solution can easily end up in the area outside the "triangles" of interest.

The area of mutual interests is where a more satisfactory resolution could lie if the parties properly investigated each other's interests and invented options to meet their mutual interests.

\section{THE INTEREST-BASED NEGOTIATOR}

The preceding section has examined the process of interest-based negotiations and the framework for setting up this type of negotiation. This next section is an attempt to complement these observations with some thoughts on the key skills and attributes of an interest-based negotiator. To set the stage, it is useful to examine yet another study which was conducted by the Neil Rackham/Huthwaite Research Group. The study attempted to discover the key behavioral attributes of a successful negotiator. The study was based on the following parameters:"

\section{Success Defined as:}

- $\quad$ rated as effective by both sides;

- $\quad$ track record of significant success over time;

- low incidence of implementation failures.

Based on:

- a ten-year study of negotiations;

- using direct behaviour analysis methods;

- forty-eight successful negotiators studied over 102 separate sessions;

- includes planning and face-to-face negotiation.

The following results were summarized as the behaviour differences between the successful and unsuccessful negotiator:

\section{Planning Stage:}

- twice as many options per issue considered;

- three and one-half times as much consideration of anticipated areas of agreement;

- twice as many comments about long-term implications;

- $\quad$ much more likely to set upper/lower limits (vs. single point objectives);

- less reliance on a planned sequence for addressing issues.

Face-to-Face Behaviour: 
- five times less use of irritators (posturing own position as more "fair," "reasonable," posturing others' position as "unfair," "unreasonable");

- half as many immediate counter-proposals;

- one quarter as many defend/attack responses;

- four times as likely to state reasons for disagreement before stating disagreement;

- twice as likely to test understanding and summarize;

- engages in argument half as frequently.

\section{Post Mortem:}

- twice as likely to review negotiation afterwards to examine what happened and how it could be improved.

A number of educators have embraced these findings and have advocated skill development in a number of areas to enhance success within the interest-based framework.

\section{RECOMMENDED SKILLS AND TECHNIQUES}

\section{A. FOCUS ON THE PROBLEM}

As we all know, negotiations are typically burdened with psychological and emotional baggage, whether it be the unhappiness and misunderstanding of each of the clients or the fact that the chemistry between you and the other lawyer is not that good. For example, maybe the other lawyer thinks you are inexperienced and should pay him the respect he deserves. Perhaps you feel nervous about dealing with a senior partner and you haven't thus far reacted well to his tone. All of these perceptions and insecurities could easily detract from the task at hand and cause miscommunication. When these psychological and emotional issues are not dealt with in an appropriate fashion, the result can include anything from reactionary language to complete aversion.

Ury and Fisher talk about separating the people from the problem. They suggest keeping a close check on your own emotions and trying your best to understand the emotions of the other negotiator. On the one side, listen to the "interference" and "selfspeak" which is taking place in your own mind. On the other side, take some time to understand the other side's perspective and be prepared to acknowledge the emotional and psychological aspects of that perspective. In taking this approach, the negotiator does not have to be "weak" or "concessionary." Ury and Fisher state that it is possible to take a soft approach to the emotional and psychological aspects of a dispute, yet to be tough on the problem. ${ }^{12}$

Be hard on the problem, soft on the people. 
One simple technique for accomplishing this goal, they suggest, is to shift the negotiation away from "you versus me" to "us versus the problem." This comparative was used earlier in the CDRC chart on the "Successful Negotiation." In focusing both of the parties on solving the problem, a cooperative approach is created which diffuses the negative aspects of psychological discord.

Educators also suggest that appropriate use of body language can be used to assist in effecting the shift towards the problem. For example, once you have established the issues and your concern for the other side's interests, move your chair closer to the other negotiator. This might further communicate that you are now on the same side. Use props such as a document to shift focus to the mutual problem. Flip charts can also be used to direct the attention of both negotiators towards the problem.

\section{B. USE APPROPRIATE COMMUNICATION TECHNIQUES}

This has been the topic of much research and could be the topic of an article in its' own right. For the purposes of this article, it is useful to know which communication skills have been identified by educators as necessary when shifting negotiations from "positions to interests" and shifting focus from "the people to the problem." Unfortunately, many of the communication skills required for interest-based negotiating are diametrically opposed to the skills which we develop as lawyers, particularly in the litigation process. Rather than attempting to force admissions and tie down a particular version of the facts, the successful interest-based negotiator is inquisitive and curious. The trick is to avoid assumptions and judgment and ask questions to which you don't know the answer.

\section{Ask Open Questions}

- explore the facts freely;

- try to find out as much as you can about the other's view;

- peel away the layers of the onion to discover the interests beneath the position;

- if interests are hard to uncover, ask questions like "How would you feel about this alternative?" Some people prefer responding to options rather than speaking directly about their interests.

\section{Listen}

- listen without interrupting or planning your response;

- maintain an open body posture;

- show interest in what the other person is saying;

- nod, make eye contact and have appropriate facial expressions.

3. Summarize Often

- test your understanding;

- check your assumptions; 
- seek clarification;

- "active listening" tells the other party you are interested;

- acknowledge the other side's perspective:

"So, you are saying that..."

"Now its my understanding that...";

- earn yourself a hearing, assure understanding before stating your point of view.

\section{Understanding does not mean agreeing.}

4. Neutralize and Refocus

- don't ignore emotional content, be empathetic;

- acknowledge emotional content but reframe its meaning in neutral language;

- refocus energy back to the merits of the problem.

Example:

"On a whim your client calls up my client at the office and starts harassing her about seeing the children. She doesn't know which end is up and she feels like she's going to snap."

"Clearly, this divorce has been overwhelming for your client and she's frustrated with the fact that there's no schedule set up for access. I agree that an access schedule has to be our key objective today."

\section{SET THE TONE FOR MUTUAL GAIN}

Educators such as Sally Campbell, who provides training for the Canadian Dispute Resolution Corporation and the Justice Institute in Vancouver, emphasize the importance of setting the tone for a successful negotiation. Introductions and opening statements can be critical in setting a tone for collaborative problem solving. Here are some statements which may prove useful in setting an appropriate climate for interestbased negotiating: ${ }^{13}$

"I think we can find a way to resolve this where we can both get what we want."

"Let's take some time to see if we can come to an agreement that we'll both feel good about."

"I want us both to leave here able to feel committed to what we agree to." 
"It's important to me to come out of this with an agreement that will work for both of us."

"What you need and what I need may seem at odds right now. Let's see if there is a way for us to both get what we need."

"I think we can work together to find a way out of this dilemma that will be acceptable to both of us."

\section{PREPARING FOR NEGOTIATIONS}

It has been said by several educators that a successful negotiator spends one hour of preparation for every two hours of negotiation. The results of the Rackham/Huthwaite study support this view and highlight areas where preparation time should be spent. ${ }^{14}$ As you may recall, the successful negotiator in that study prepares by:

- expanding the number of options per issue;

- considering anticipated areas of agreement.

In order to generate options and anticipate areas of agreement, considerable preparation time should be spent exploring your client's interests. What are his or her hopes, fears, desire and concerns? In addition, what are the possible interests of the other party?

After generating possible options, William Ury suggests addressing what your best option will be if the negotiation is not a success. For example, your client has worked hard in preparing a proposal for the supply of computer equipment to a firm. The negotiating session will most likely lead to a long term deal soon. Before the session, Ury suggests encouraging your client to examine the options if the deal is a bust. Could the proposal be shopped elsewhere? How much would the other possible buyer be prepared to pay? Instead of setting a hopeful position, it is important to know the point at which you will walk away from the negotiation.

Know your best alternative to a negotiated agreement (BATNA)

Knowing your BATNA increases your confidence at the negotiating table. In our example, if the purchaser of computer equipment suddenly tried to slash the price by 20 percent, you would be in a better position to assess whether such a reduction would meet with your client's interests if you had assessed your client's best alternative. Having an alternative in your back pocket provides you with the necessary context to the negotiating process. ${ }^{15}$ 
Finally, Fisher and Ury also recommend using preparation time to develop appropriate standards for evaluating the options at the negotiating table. For example, Fisher states that if you are negotiating for a community organization which is concerned about safety at a nearby construction site, take some time to develop a standard for measuring options to meet that interest. Contact the local construction association to obtain accepted construction practices. In the alternative, contact other construction companies for their construction procedures and safety practices. Presenting appropriate standards is a useful method of evaluating possible solutions after brainstorming with the other negotiator.

\section{E. PRACTICE FREQUENT SELF-EVALUATION}

We now turn once again to the issue of "style." As discussed earlier, some writers suggest that style can and does form the basis for negotiations. For example, patterns of cooperative or aggressive style will play off against each other to result in a process and final outcome which can be studied and predicted. Still, other writers do not see style analysis as a useful method for encouraging skill development. They say "style" and the behavioral patterns of the negotiator are too unpredictable to use as variables for establishing a model for successful negotiating. In my view, this latter perspective is preferred. Arguably, styles such as the cooperative or aggressive style are each reactions to the problems arising from positional negotiations. To borrow Folberg and Taylor's analogy, positional negotiations highlight the divergent aspects of conflict and result in the negotiator infusing his or her own psychological reaction into the negative dynamic. As a result of the positional forces, each party reacts in an attempt to avoid losing face and to force the other to move towards his or her position.

In this context, style is simply one way of describing who we are as people. In the context of negotiating, style is about how we react to conflict. Are you a problem solver at all costs? Do you view conflict as a contest of the fittest? Do you recoil from anger? Do you immediately react when attacked? In certain moments and at certain stages in the negotiating process, these psychological characteristics can be both strengths and weaknesses. Regardless of the negotiating technique or framework employed, the "style" of a negotiator forms a very important layer over the methodology employed. Whether the technique is interest-based negotiating or any other framework for negotiation, "style" is the psychological component that we, as negotiators, bring to the table.

Educators say it is of critical importance to understand how you as a negotiator react to conflict. In this way you can guard against "folding when the going gets tough" or "counter-attacking before you are fully informed." These kinds of psychological responses interfere with the manner in which a negotiator applies his or her skills.

The easiest way to conduct self-evaluation is to review each negotiation carefully. Ask yourself how you reacted to the most difficult of the challenges. How might you have approached the situation differently? In addition, it may be useful to consult 
educational tools for self-evaluation. Thomas and Killman have devised a helpful quiz and graph for this purpose. ${ }^{16}$

\section{A COMPLETE FRAMEWORK FOR SUCCESSFUL NEGOTIATIONS}

Having now examined the key elements of interest-based negotiations and evaluated the key attributes of an interest-based negotiator, it would be useful to summarize the topic with a step-by-step framework for conducting an interest-based negotiation. It is important to note, however, that writers have generally discouraged becoming a slave to the framework. As you well know, every negotiation is different. Arguably the most important attribute of a successful negotiator is flexibility. ${ }^{17}$

\section{THE FOUR STAGE NEGOTIATION MODEL ${ }^{18}$}

\section{PRE-NEGOTIATION PREPARATION AND ASSESSMENT}

STAGE I Agree on the Guidelines and Set a Tone for Effective Negotiations

- Begin to create a positive environment which will support effective negotiations (rapport);

- Discuss mutually desirable guidelines;

- Begin to separate the problem from the people;

- Agree on the general purpose for the negotiations.

STAGE II Outline the Issues/Describe the Problem

- Each negotiator has uninterrupted time to briefly outline the issues from his/her perspective;

- Mutually clarify each other's understanding of the issues;

- Agree on an agenda.

STAGE III Move from Positions to Interests (Needs, Concerns/Fears)

- Breakdown larger issues into sub-issues;

- Seek information to determine the underlying interests;

- Determine what is important and why;

- Identify mutual interests or areas of common interest;

- Continue to encourage understanding of each other's point of view through clarification.

STAGE IV Negotiate an Agreement that Works: Problem-Solve

See K. Thomas, "Conflict and Conflict Management" in Dunnette, ed., The Handbook of Industrial and Organizational Psychology (Chicago: Rand McNally, 1976) 889.

Supra note 3 at 49.

Ibid. at 20. 
- Create options for solutions;

- Evaluate the options using objective criteria;

- Discuss plans for implementation - be practical and realistic;

- Be specific - discourage ambiguity;

- Draft the agreement.

One important note about this framework: it is not necessarily a process which proceeds from beginning to end. The framework is better described as a cycle. For example, the negotiators may be in the process of brainstorming for options when a new issue comes to the surface. At that point it may be appropriate to focus on that issue, return to Stage II, explore the issues pertaining to that issue, and then proceed back to brainstorming solutions.

In order to feel comfortable with this process, you may want to try a few practice sessions. At your nearest library you will find books on negotiating which contain role play exercises. The role play is also a very useful context for trying out new communication techniques and self-evaluation.

\section{FINAL COMMENTS}

The ideas described in this article with respect to negotiating are at the crest of the wave with respect to alternate dispute resolution theories. As you know, negotiating is just one method of dispute resolution, with others such as mediation and conciliation forming part of the wave.

High Degree of Third Party

Decision-Making

\begin{tabular}{|c|c|c|c|c|}
\hline - Litigation & - Arbitration & - Mediation & - Conciliation & - Negotiation \\
\hline
\end{tabular}

High Degree of Control by Participants

The above dispute resolution continuum illustrates the close proximity of methods which resolve disputes without a third-party decision maker. The nearness of negotiation, mediation, and conciliation in the continuum is one explanation for the similarity of theories used by mediators, conciliators and some negotiators. For example, mediation training has also adopted the interest-based approach. Skill development includes improving communication skills to help the participants in the mediation discover the interests beneath their positions.

In view of the increasing use of such mechanisms as mediation and conciliation, time spent on negotiation skill development is time well spent. Not only is it sure to make us better lawyers for the future, but arguably it will also make us better people today. 